\title{
Pembatalan Perjanjian Pengikatan Jual Beli Hak Milik Atas Tanah
}

\author{
Ni Luh Yunik Sri Antari
}

Fakultas Hukum Universitas Udayana, E-mail: yuniksriantari@gmail.com/WA : 081338514077

\begin{tabular}{l}
\hline Info Artikel \\
\hline Keywords : \\
Cancellation of agreement, \\
ownership, over land \\
Corresponding Author: \\
Ni Luh Yunik Sri Antari, \\
E-mail: \\
yuniksriantari@gmail.com \\
Pata kunci: \\
Milik, Atas Tanah \\
Pembatalan perjanjian, Hak
\end{tabular}

\begin{abstract}
The agreement on binding sale and purchase of land rights often experiences obstacles in practice. issues related to the agreement can result in the agreement being canceled. Cancellation of the agreement certainly causes losses to the parties so that there needs to be a protection due to the cancellation of the agreement. This writing aims to be able to know and analyze more deeply related to the legal consequences of the cancellation of the sale and purchase agreement on land rights and legal protection that can be granted in the cancellation of the agreement. This study uses a type of normative research. Moving on from the norm vacuum related to the cancellation of the sale and purchase agreement. So that it can be seen from the results of research related to the cancellation of the sale and purchase agreement that has been made can lead to legal consequences and agreements that have previously been made invalid or in other words the agreement ends and the parties are no longer bound as long as necessary as set in Article 1266 and 1267 Civil Code. Furthermore, the related parties will be fined for delays calculated every day. For the parties the legal protection that should be given is the condition of being returned as before before the binding agreement on the sale and purchase of land, money previously paid by the buyer to the seller, must be returned by the seller to the buyer and vice versa due to the cancellation of the agreement. return his property.
\end{abstract}


dan perjanjian yang sebelumnya telah dibuat menjadi tidak berlaku lagi atau dengan kata lain perjanjian tersebut menjadi berakhir dan para pihak tidak lagi terikat sepanjang diperlukan seperti yang telah di tetapkan dalam Pasal 1266 dan 1267 KUHPerdata. Selanjutnya bagi para pihak terkait akan di kenakan denda atas keterlambatan yang dihitung setiap harinya. Bagi para pihak perlindungan hukum yang seharusnya diberikan yaitu keadaan menjadi dikembalikan seperti sediakala sebelum adanya perjanjian pengikatan jual beli tanah, uang yang sebelumnya telah dibayarkan oleh pembeli kepada penjual, harus dikembalikan oleh penjual kepada pembeli dan sebaliknya karena pembatalan perjanjian tersebut maka si penjual berhak untuk mendapatkan kembali hak miliknya.

\section{Pendahuluan}

Perjanjian jual-beli merupakan perjanjian konsensuil, dimana perjanjian tersebut sah dan memiliki kekuatan mengikat sejak tercapainya kata sepakat antara penjual dan pembeli sehubungan dengan unsur-unsur dasar (essentialia) mengenai barang dan harga, barang disini termasuk barang tak bergerak. Dalam Pasal 1458 KUHPerdata yang merupakan gambaran dari sifat konsensuil dalam perjanjian jual beli dalam pasal tersebut menyatakan: "Dimana Jual-beli dianggap sudah terjadi diantara kedua belah pihak pada saat mereka telah mencapai kata sepakat terhadap barang dan harga, walaupun barang tersebut belum diserahkan ataupun harganya belum dibayar." Dalam perjanjian jual-beli, pihak penjual menjanjikan akan memindahkan dan menyerahkan hak miliknya atas barang tersebut, kemudian pihak kedua sebagai pembeli akan membayar harga sesuai dengan kesepakatan. ${ }^{1}$ Pembuatan perjanjian dihadapan notaris harus dilakukan apabila akan melaksanakan Jual-beli dimana adapun persyaratan yang harus dipenuhi yaitu telah terpenuhinya syarat terang dan tunai, kemudian pada selanjutnya akan dilakukan penandatangan akta jual beli di hadapan Pejabat Pembuat Akta Tanah (PPAT). Segala ketentuan yang mengatur tentang jenis peralihan, jual beli dan peralihan hak atas tanah, telah diatur dalam Pasal 37 ayat (1) Peraturan Pemerintah Nomor 24 Tahun 1997 tentang Pendaftaran Tanah (Lembaran Negara Nomor 59 Tahun 1997, Tambahan Lembaran Negara Nomor 3696), yang menyebutkan bahwa: beralihnya suatu hak milik atas tanah, baik itu satuan rumah susun dengan jual-beli, tukar menukar, dengan hibah, serta adanya pemasukan harta kedalam sebuah perusahaan serta jenis perbuatan hukum pemindahan hak lainnya, terkecuali adanya pemindahan hak disebabkan karena adanya proses lelang terlebih dahulu, dapat didaftarkan apabila bisa di buktikan dengan akta PPAT, karena PPAT lah yang berwenang untuk membuat akta menyangkut pelelangan sesuai dengan peraturan perundang-undangan yang telah diberlakukan. Dengan demikian jika belum terpenuhunya semua persyaratan yang telah ditentukan oleh peraturan perundang-undangan yang telah diberlakukan, maka pemindahan Hak atas tanah dengan cara dialihkan tidak dapat dilakukan begitu saja.

${ }^{1}$ Subekti, R. (2002). Hukum Perjanjian. Jakarta:PT. Intermasa. h. 79 
Dalam rangka memberikan jaminan kepastian hukum, sudah seharusnya perjanjian jual beli tersebut dibuatkan dalam bentuk akta otentik yaitu dibuat oleh notaris. Akta notaris yang telah ditandatangani dan diresmikan memiliki peranan sebagai alat bukti otentik. Akta otentik sebagai bukti yang lengkap (mengikat) memiliki arti bahwa halhal yang tertulis dalam akta tersebut benar dan harus diakui oleh hakim, selama tidak ada pihak lain yang dapat membuktikan sebaliknya. ${ }^{2}$ Perjanjian senantiasa bisa berjalan dengan lancar sesuai dengan apa yang telah menjadi kesepakatan diantara kedua belah pihak. Ada hal-hal tertentu yang dapat membawa akibat batalnya suatu perjanjian yang sebelumnya telah disepakati, pembatalan tersebut dapat dilakukan oleh para pihak maupun berdasarkan putusan pengadilan.

Perjanjian pengikatan jual-beli (PPJB) hak milik atas tanah adalah suatu perbuatan hukum yang mendahului proses peralihan hak milik atas tanah. PPJB merupakan perjanjian yang dilakukan oleh penjual dan pembeli sebelum pelaksanaan jual beli, hal ini dikarenakan adanya unsur-unsur yang harus dipenuhi untuk jual beli tersebut. Dalam hal PPJB tanah, permasalahan yang mungkin akan muncul akibat belum terpenuhinya unsur-unsur jual beli yaitu sertifikat tanah yang belum jadi karena sedang dalam proses, atau belum terjadi pelunasan pembayaran terhadap tanah tersebut, atau belum melakukan pembayaran atas pajak-pajak yang dikenakan terhadap jual beli tanah tersebut. Dalam PPJB ditentukan, para pihak yang akan melakukan jual beli sudah terikat dan mempunyai hak dan kewajiban untuk menaati perjanjian. ${ }^{3}$ Sebagai suatu perikatan, perjanjian jual-beli tanah mengandung hak dan kewajiban dari para pihak yang membuatnya, sehingga apabila hal-hal yang telah disepakati dalam perjanjian jual-beli tersebut dilanggar atau tidak dipenuhi oleh para pihak yang membuatnya maka dapat dikatakan telah terjadi wanprestasi.

Wanprestasi adalah keadaan dimana salah satu pihak tidak melaksanakan kewajibannya, atau melaksanakan perjanjian tapi hanya sebagian, sehingga mengakibatkan kerugian bagi pihak yang lainnya. Wanprestasi dapat berakibat kepada pembatalan perjanjian. Mengenai pembatalan perjanjian dapat dilihat dari ketentuan Pasal 1266 KUHPerdata yang menyatakan bahwa terdapat tiga hal yang dapat mengakibatkan pembatalan suatu perjanjian yaitu sebagai berikut: a. para pihak saling memperjanjikan secara timbal balik yaitu saling memberikan prestasi terkait satu sama lain, jika salah satu pihak tidak memenuhi prestasi maka akan terhubung langsung kepada pihak lainnya yang sudah memenuhi prestasi. Dengan demikian apabila ada salah satu pihak telah melakukan wanprestasi karena tidak memenuhi isi dari perjanjian yang telah dibuat maka pihak lawan berhak untuk mengajukan untuk perjanjian tersebut dibatalkan. Tetapi dari pihak lawan apabila dia juga melakukan wanprestasi maka dia tidak mempunyai hak untuk mengajukan pembatalan pada perjanjian tersebut. b. syarat batal dicantumkan ketika pihak lawan telah melakukan wanprestasi dan tercantum dalam perjanjian timbal balik apabila prestasi atau kewajibannya tersebut tidah dipenuhi oleh salah satu pihak. (Pasal 1266 KUH Perdata). c. Pembatalan terkait perjanjian tersebut harus dilakukan melalui putusan Pengadilan Negeri. Pembatalan pada gugatan wanprestasi harus dituntut oleh salah

\footnotetext{
2 Samudera, T. (2004). Hukum Pembuktian Dalam Acara Perdata, Bandung: Alumni. h. 49

${ }^{3}$ Dewi, R.P. and Purwadi. H. "PEMBATALAN AKTA PERJANJIAN PENGIKATAN JUAL BELI AKIBAT WANPRESTASI (Studi Kasus Putusan Nomor: 200/Pdt. G/2012/PN. Jkt. Sel)." Jurnal Repertorium 4.2 (2017).143-151, h.143
} 
satu pihak. Kata harus dalam ketentuan Pasal 1266 KUH Perdata ditafsirkan bersifat memaksa oleh karena itu tidak diperbolehkan untuk ditentang atau disimpangi melalui perjanjian mereka. Apabila kesalahan terkait wanprestasi terbilang relative masih kecil, maka hakim berwenang untuk menolak tuntutan pembatalan tersebut. Ada dua cara untuk mengajukan pembatalan perjanjian tersebut yaitu yang pertama, pihak yang berkepentingan melakukan gugatan perdata atas perbuatan wanprestasi, mengajukan gugatan tersebut ke Pengadilan Negeri setempat serta mengajukan permohonan kepada hakim agar PPJB tersebut dapat dibatalkan. Kedua yaitu dengan cara menunggu ada yang menggugatnya, sampai dia digugat dari pihak lainnya melalui gugatan Pengadilan Negeri setempat. Berdasarkan barang bukti, fakta dalam persidangan, dan keterangan para saksi selama proses persidangan berlangsung, maka dari itu hakim akan membuat dasar pertimbangan untuk memeberikan putusan atau memutus perkara perdata terkait telah dibatalkannya perjanjian jual beli hak milik atas tanah tersebut. Pembatalan perjanjian tentunya membawa dampak yang merugikan sehingga diperlukan adanya suatu perlindungan hukum atas pembatalan perjanjian PPJB hak milik atas tanah. Berdasarkan uraian diatas maka menarik untuk dilakukan penelitian lebih lanjut dengan judul "PEMBATALAN PERJANJIAN PENGIKATAN JUAL BELI HAK MILIK ATAS TANAH." Adapun permasalahan dalam penelitian ini adalah sebagai berikut: Bagaimanakah akibat hukum dari pembatalan perjanjian pengikatan jual beli hak milik atas tanah? dan Bagaimanakah perlindungan hukum yang dapat diberikan dalam pembatalan perjanjian pengikatan jual beli hak milik atas tanah?

Tujuan Penelitian ini secara umum adalah untuk mengembangkan khazanah pemikiran hukum terutama hukum agraria dan hukum perjanjian tentang pembatalan perjanjian pengikatan jual beli hak milik atas tanah. Sedangkan yang menjadi tujuan khusus penelitian ini adalah untuk dapat mendeskripsikan dan melakukan analisa lebih lanjut mengenai akibat hukum dari pembatalan perjanjian pengikatan jual beli hak milik atas tanah. Serta untuk dapat lebih memahami dan melakukan analisa lebih lanjut tentang perlindungan hukum yang dapat diberikan dalam pembatalan perjanjian pengikatan jual beli hak milik atas tanah.

\section{Metode Penelitian}

Dalam penelitian ini menggunakan jenis penelitian hukum normatif. Dengan mengkaji berbagai jenis bahan-bahan yang berasal dari beberapa peraturan perundangundangan. Terdapat tiga macam sumber bahan hukum, yaitu: yang pertama merupakan bahan hukum primer merupakan bahan hukum yang sifatnya mengikat dan memaksa orang-orang untuk mematuhi atau mengikutinya. Yang kedua merupakan bahan hukum sekunder merupakan pendukung dari bahan hukum primer, atau dengan kata lain bahan hukum sekunder dapat membantu menjelaskan bahan hukum primer. Kemudian yang terakhir yaitu bahan hukum yang ketiga adalah bahan hukum tertier adalah pendukung selanjutnya atau pelengkap bagi bahan hukum primer dan bahan hukum sekunder. ${ }^{4}$ Penelitian hukum normatif yang digunakan ini bersumber dari hasil penelitian kepustakaan (Library Research). Sumber bahan hukum yang digunakan merupakan sumber bahan hukum yang berasal dari peraturan perundang-undangan yang berasal dari bahan hukum primer, bahan

${ }^{4}$ Ibid, h. 13. 
hukum sekunder terdiri literatur-literatur, buku-buku, makalah, dokumen-dokumen yang terkait dengan masalah yang dibahas, dan bahan hukum tertier yang terdiri dari kamus dan ensiklopedi. Dalam penelitian ini menggunakan bahan hukum yang berasal dari hasil penelitian kepustakaan dengan cara memplajari secara lebih mendalam kemudian selanjutnya dilakuan pengkajian terkait dengan sumber perturan perundangan-undangan yang ada hubungannya dengan permasalahan yang dibahas baik secara langsung ataupun tidak langsung.

\section{Hasil Dan Pembahasan}

\subsection{Akibat Hukum Pembatalan Perjanjian Pengikatan Jual Beli Hak Milik Atas Tanah}

Sebuah perjanjian atau persetujuan bukan saja mengenai segala hal yang telah secara jelas diperjanjikan, tetapi juga menyangkut pada hal-hal yang berdasarkan atas sifat dari persetujuan itu sendiri dapat dituntut atas dasar kebiasaan, keadilan, dan juga atas dasar undang-undang. Mengenai syarat-syarat yang terkandung dalam sebuah perjanjian, meskipun tidak tercantum secara jelas dan tegas dalam perjanjian tersebut, apabila sudah merupakan sebuah kebiasaan, maka syarat-syarat tersebut haruslah dianggap sudah tercantum didalam sebuah perjanjian tersebut. Perjanjian mengikat para pihak yang membuatnya dan berlaku sebagai undang-undang bagi para pihak (KUH Perdata Pasal 1338). Namun terdapat pembatasan mengenai hal tersebut, khususnya dalam hukum pertanahan, yaitu adalah selama persetujuan atau perjanjian yang dilakukan tersebut telah mengikuti dan sesuai dengan aturan-aturan didalam UUPA. ${ }^{5}$ Kesepakatan didalam sebuah perjanjian dianggap telah terjadi pada saat salah satu pihak telah menerima atau menyanggupi penawaran (offerte) yang diberikan oleh pihak lainnya. Sebuah perjanjian yang telah dibuat tidak bisa dibatalkan begitu saja dari satu pihak tanpa adanya persetujuan dari pihak lainnya. Dalam perjanjian sangat perlu agar diketahui, hal ini sehubungan dengan apabila terjadinya perubahan atas aturan perundang-undangan terkait yang dapat membawa dampak terhadap perjanjian itu sendiri. Contohnya adalah mengenai peralihan sebuah risiko didalam sebuah perjanjian jual beli. ${ }^{6}$

Perjanjian jual beli hak milik atas tanah bisa diartikan sebagai sebuah perjanjian yang para pihaknya sepakat untuk mengalihkan hak milik melalui jual beli terhadap suatu objek yaitu tanah itu sendiri, jika terdapat satu atau beberapa hal yang belum atau tidak mampu terpenuhi disaat perjanjian dilaksanakan, yang dalam hal ini pada umumnya terkait dengan pembayaran yang belum dilunasi dan juga mengenai kelengkapan dokumen atau surat-surat dari tanah tersebut. Pengikatan Jual Beli (PJB) tanah bisa dibuat dan dilaksanakan oleh para pihak yang bersangkutan dengan membuat akta dibawah tangan maupun dibuat dengan akta notaris. Dalam hal ini baik tanah yang sudah memiliki Sertipikat Hak Milik (SHM) maupun tanah yang belum memiliki SHM pembuatan PJB keduanya dapat dilakukan dihadapan notaris. PJB tanah yang telah memiliki SHM adalah sebuah perbuatan hukum yang mengawali

\footnotetext{
${ }^{5}$ Sancaya, I. W. W. (2013). Kekuatan Mengikat Perjanjian Nominee dalam Penguasaan Hak Milik Atas Tanah. Jurnal Magister Hukum Udayana (Udayana Master Law Journal), 2(3).h.6 ${ }^{6}$ Santosa, K., \& Hanim, L. (2017). PERLINDUNGAN HUKUM BAGI PIHAK-PIHAK YANG BERITIKAD BAIK DALAM PEMBATALAN PERJANJIAN JUAL BELI TANAH DAN BANGUNAN (Studi Kasus Nomor 29/Pdt. G/2014/PN. Wsb).Jurnal Akta, 4(2), 167-173. h.168
} 
terjadinya perbuatan hukum berikutnya yaitu jual beli hak atas tanah. Maka dari itu terdapat perbedaan antara PJB dengan jual beli. Seorang notaris mempunyai kewenangan dalam rangka pembuatan akta PJB terhadap tanah yang berstatus SHM, tetapi tidak memiliki kewenangan terkait pembuatan Akta Jual Beli (AJB) tanah tersebut, dikarenakan kewenangan terkait pembuatan AJB tanah berstatus SHM adalah milik Pejabat Pembuat Akta Tanah (PPAT). ${ }^{7}$

Sebuah perjanjian jual beli memungkinkan untuk dilakukannya pembatalan baik atas keputusan bersama maupun secara sepihak. Selain itu pembatalan perjanjian jual beli dapat juga dilakukan berdasarkan keputusan dari Pengadilan Negeri setempat atas dasar permohonan dengan cara melakukan gugatan secara perdata. Namun dengan terjadinya pembatalan terhadap perjanjian yang telah dibuatkan aktanya dihadapan notaris, maka pastinya akan memiliki permasalahan hukum yang harus diterima. Salah satu permasalahan yang akan mungkin terjadi yaitu pembeli tidak akan melanjutkan pembayaran kepada penjual sebagaimana yang telah dijanjikan seharusnya, sehingga penjual tidak akan menerima sisa pembayaran terkait penjualan hak atas tanahnya tersebut. Selain itu ada juga masalah yang mungkin akan terjadi dikarenakan proses angsuran pelunasan pembayaran yang dilakukan oleh pembeli yang memakan waktu terlalu lama, sehingga kesepakatan kemudian diakhiri atau dibatalkan dikarenakan pihak penjual memutuskan untuk memberikan tanahnya kepada penjual yang lainnya. ${ }^{8}$ Sebuah akta otentik sebagaimana diamanatkan didalam ketentuan Pasal 1868 KUH Perdata yaitu merupakan suatu akta yang didalam bentuk yang ditentukan oleh undang-undang, dibuat oleh atau dihadapan pegawai-pegawai umum yang berkuasa untuk itu tempat dimana akta dibuatnya. Suatu akta otentik merupakan salah satu alat bukti dengan pembuktian sempurna yang dapat dipergunakan dalam persidangan.

Suatu akta otentik sebagaimana diamanatkan dalam ketentuan Pasal 1868 KUH Perdata yaitu suatu akta yang didalam bentuk yang ditentukan oleh undang-undang, dibuat oleh atau dihadapan pejabat umum yang berkuasa untuk itu tempat dimana akta dibuatnya. Suatu akta otentik merupakan salah satu alat bukti dengan pembuktian sempurna yang dapat dipergunakan salam persidangan.

Dalam perkara perdata didalam persidangan terdapat beberapa macam alat bukti, antara lain perkataan atau ucapan berupa keterangan dari saksi-saksi, pengakuan, sumpah serta tulisan-tulisan yang dapat membuktikan suatu kejadian yang telah terjadi. Selain itu ada pula alat bukti berupa alat bukti elektronis baik itu yang disimpan ataupun yang direkam dengan cara elektronis dan merupakan alat bukti yang sah di persidangan. Akta notaris merupakan akta yuridis karena, yang pertama akta notaris dibuat berdasarkan yang telah ditentukan oleh undang-undang, yang kedua akta yang dibuat oleh notaris berdasarkan permintaan dari para penghadap atau para pihak, yang ketiga walaupun pada akta terdapat nama notaris tetapi bukan berkedudukan sama seperti para pihak yang namanya ditulis pada akta tersebut, yang keempat akta notaris berlaku sebagai alat bukti sang sah atau sempurna dan mengikat

\footnotetext{
7 BASWEDAN, T. B. T. (2014). Kajian Yuridis Pembatalan Akta Pengikatan Jual Beli (Pjb) Tanah yang Dibuat Dihadapan Notaris. PREMISE LAW JURNAL, 4.1-18, h.3

8 Alfiansyah, A. (2015). Urgensi Perjanjian Pengikatan Jual Beli (Ppjb) Hak Atas Tanah yang Dibuat oleh Notaris. Kumpulan Jurnal Mahasiswa Fakultas Hukum.1-21, h.5
} 
serta tidak bersifat multitafsir, dan yang kelima hanya para pihak yang dapat melakukan pembatalan terhadap daya ikat akta notaris yang telah dibuat berdasarkan kesepakatan para pihak, apa bila ada salah sati pihak ada yang tidak menyetujuinya maka tindakan yang harus dilakukan yaitu harus melakukan permohonan ke pengadilan umum, agar akta yang telah ada tidak dapat berlaku mengikat lagi para pihak tentunya harus dengan alasan yang dapat dibuktikan. ${ }^{9}$

Seorang notaris wajib untuk menjelaskan kepada siapapun yang menghadap agar perbuatan dan tindakan notaris tersebut sesuai dengan peraturan yang ada. Apabila para pihak menganggap akta notaris tersebut tidak sesuai dengan yang diharapkan, maka pihak-pihak terkait dapat datang bersama ke hadapan notaris yang bersangkutan agar akta tersebut selanjutnya dapat dibatalkan. Didalam tatanan hukum kenotariatan, terkait dengan akta, apabila suatu akta dikemudian hari di permasalahkan oleh para pihak, maka pihak-pihak terkait dapat menghadap ke notaris yang bersangkutan untuk membatalkan akta yang pernah dibuatnya, sehingga para pihak yang terkait tidak lagi terikat dengan isi dari akta yang dibatalkan tersebut, namun pihak-pihak yang bersangkutan harus bersedia untuk bertanggung jawab terhadap akibat-akibat yang akan terjadi dengan dibatalkannya akta tersebut. Didalam sebuah keadaan tertentu apabila terjadi cacat tertentu didalam sebuah perjanjian, maka perjanjian tersebut akan dianggap batal demi hukum. Sebuah perbuatan hukum yang memiliki cacat tetapi yang menentukan sah atau dianggap batal tergantung kepada keingingan dari orang tertentu sehingga perbuatan hukum tersebut dapat dibatalkan. Syarat batalnya dianggap tercantum didalam persetujuan-persetujuan yang memiliki timbal balik, ketika satu pihak tidak menjalankan kewaajibannya. Ketika terjadi hal seperti itu, persetujuan bukanlah batal demi hukum, namun pembatalanya perlu dimintakan kepada hakim. Pembatalan berlaku sejak putusan hakim yang memperoleh kekuataan hukum yang tetap (ex nunc). ${ }^{10}$

Mengenai dibatalkannya sebuah akta notaris, dalam hal ini, oleh Pengadilan dimulai dengan proses diperiksanya sebuah perkara di pengadilan yang sudah didaftarkan di kepaniteraan Pengadilan Negeri. Hari dan jam perkara akan diperiksa dimuka sidang kemudian ditentukan oleh Ketua Majelis Hakim. Hakim dan pengadilan adalah alat kelengkapan dalam sebuah negara hukum yang diberi tugas untuk menetapkan hubungan hukum yang sesungguhnya antara pihak-pihak yang terlibat dalam sebuah sengketa. Sebuah akta notaris yang dianggap batal menjadi akta otentik, akta tersebut tetap bisa berfungsi menjadi akta dibawah tangan jika akta tersebut telah ditandatangani pihak-pihak yang bersangkutan, selama perubahan status akta tersebut tidak membawa kerugian bagi pihak terkait, maka notaris yang bersangkutan tidak bisa dituntut, meskipun notaris tersebut akan kehilangan nama baiknya.

Akibat hukum adalah akar dari timbulnya kewajiban dan hak bagi subjek hukum yang terkait. Contohnya, dengan melakukan perjanjian jual beli maka timbul sebuah akibat hukum yaitu penjual berkewajiban untuk menyerahkan barang dan berhak menerima pembayaran, sedangkan pembeli berkewajiban untuk membayar dan berhak untuk

\footnotetext{
${ }^{9}$ Ibid, h. 137

10 Ardianti, M., \& Handayani, I. G. A. K. R. (2018). PENYALAHGUNAAN WEWENANG PENERIMA KUASA DALAM PERJANJIAN PERIKATAN JUAL BELI TANAH DAN KUASA MENJUAL (Putusan Nomor: 173/K/Pdt/2012). Jurnal Repertorium, 5(1). h.179
} 
menerima barang yang diperjualbelikan. Mengenai pembatalan terhadap jual beli akan menimbulkan akibat hukum yaitu: 1. Berakhirnya sebuah perjanjian dan selama dibutuhkan para pihak dapat melepas diri dari hal-hal yang telah ditentukan didalam Pasal 1266 dan Pasal 1267 KUHPerdata, dan penjual berkewajiban untuk mengembalikan uang sejumlah yang tealah dibayar oleh pembeli setelah dipotong beberapa persen dari harga jual yang ditetapkan sebagai bentuk ganti dari biaya yang telah dikeluarkan oleh penjual dengan ditambahkan denda yang perlu dibayarkan oleh pembeli kepada penjual. Dikembalikannya uang dari penjual ke pembeli dilaksnakan paling lambat sesuai waktu yang disepakati. 2. Pihak-pihak bisa dikenai denda yang jumlahnya disesuaikan dengan kesepakatan bersama yang wajib dibayarkan oleh pembeli kepada penjual maupun sebaliknya, untuk setiap hari keterlambatan yang semestinya dibayarkan dengan sekaligus. Pertanggungjawaban para pihak terhadap perbuatannya adalah kewajiban masing-masing pihak tersebut. Akibat hukum dari dijatuhkannya putusan oleh pengadilan, dalam kaitannya dengan ini notaris tidak memiliki tanggung jawab terhadap rugi yang dialami oleh pihak yang kalah, dan notaris tidak bisa dituntut atas kerugian terhadap biaya dari pembuatan akta yang bersangkutan.

\subsection{Perlindungan Hukum Yang Dapat Diberikan Dalam Pembatalan Perjanjian Pengikatan Jual Beli Hak Milik Atas Tanah}

Perbuatan hukum yang mengakibatkan peralihan hak atas tanah serta harus didaftarkan balik namanya adalah perbuatan hukum jual-beli dimana aktanya dibuat dalam AJB yang dibuat oleh PPAT yang biasa disebut dengan AJB balik nama, AJB tersebut selanjutnya digunakan sebagai alat pendaftaran peralihan hak atas tanah. ${ }^{11}$ terkait perjanjian jual beli hak milik atas tanah, pihak penjual mengalihkan hak milik atas tanahnya kepada pembeli yang sebelumnya telah ditentukan dan sesuai kesepakatan yang disepakati dan dicantumkan dalam perjanjian jual beli. Perjanjian tersebut terkait dengan Pasal 1320 KUHPerdata tentang syarat sahnya suatu perjanjian yang menentukan ${ }^{12}$

PPJB adalah sebagai perjanjian yang mengawali dan menjelaskan bahwa para pihak terkait ikatan melakukan perjanjian utama yaitu perjanjian jual beli, dan melakukan sebuah hubungan hukum diatara pihak-pihak, jika perjanjian yang telah disetujui dalam pengikatan jual beli itu telah dijalankan sepenuhnya. ${ }^{13}$

Sebuah perjanjian yang dibatalkan sebab adanya sebuah permohonan dari pihak yang menginginkannya, yaitu pihak orang tua, wali, maupun pengampu dikatakan sebagai pembatalan relative atau pembatalan tidak mutlak, yang dapat dibagi menjadi ${ }^{14}$ :

11 Sumardi, S. H. "KEDUDUKAN KUASA MENJUAL ATAS DASAR SURAT KETERANGAN NOTARIS TENTANG PEMBAYARAN LUNAS DALAM PEMBUATAN AKTA JUAL BELI BALIK NAMA." Acta Comitas.H.2

12 Dewi, R. P., \& Purwadi, H. (2017). PEMBATALAN AKTA PERJANJIAN PENGIKATAN JUAL BELI AKIBAT WANPRESTASI (Studi Kasus Putusan Nomor: 200/Pdt. G/2012/PN. Jkt. Sel). Jurnal Repertorium, 4(2). h.144

13 SITINJAK, MELDA NEHEMIA. Analisis Yuridis terhadap Perjanjian Pengikatan Jual Beli (Ppjb) Unit Apartemen sebagai Agunan dalam Perjanjian Kredit Investasi (Studi di Pt. bank Nationalnobu Tbk). PREMISE LAW JURNAL, 2016, 21.h.7

${ }_{14}$ Projodikoro, W. (2003). Asas-Asas Hukum Perjanjian. Bandung: Sumur. h. 121 
1. Tentang pembatalan dengan mengajukan gugatan kepada hakim. (pasal 1446 KUHPerdata);

2. Pembatalan oleh hakim melalui putusan, (Pasal 1449 KUHPerdata).

Sebuah syarat subjektif dapat terancam akan dibatalkan oleh para pihak yang bersangkutan yaitu pihak orang tua, wali maupun pengampu. Dalam rangka untuk mencegah adanya hal ini maka pihak-pihak didalam perjanjian tersebut dapat dimintai ketegasan bahwa perjanjian yang telah dibuat tetap akan dilaksanakan dan mereka tetap terikat dengan perjanjian tersebut. ${ }^{15}$ Jika syarat objektif tidak dapat dipenuhi, maka perjanjian akan dianggap batal demi hukum, bahkan tanpa diperlukan persetujuan dari para pihak. Maka dari itu perjanjian tersebut akan diaggap tidak pernah dibuat dan tidak mengikat pihak siapapun. Perjanjian yang mutlak dianggap batal dapat pula terjadi apabila unsur-unsur didalam Pasal 1320 KUPerdata tidak terpenuhi oleh para pihak, dan perjanjian yang dibuat tidak jelas objeknya, dan melanggar undang-undang, kesusilaan dan kepatutan. Pembatalan ini dikatakan juga sebagai pembatalan mutlak (absolute nietigheid).

Terkait dengan perlindungan hukum kepada pihak-pihak yang terlibat didalam sebuah perjanjian, sebelumnya mengenai perlindungan hukum itu sendiri terdiri dari dua suku kata yaitu perlindungan yang memiliki arti perbuatan melindungi, sedangkan hukum itu sendiri sebuah aturan dalam rangka untuk menjamin dan menjaga kepentingan semua pihak. Maka dari itu perlindungan hukum merupakan semua perbuatan yang akan memberikan perlindungan kepada hak-hak dari subjek hukum sesuai dengan aturan yang berlaku. Terdapat beberapa perlindungan terkait dengan wanprestasi didalam perjanjian jual beli yaitu diantaranya adalah:

1. Perlindungan terhadap penjual yaitu merupakan syarat yang umumnya diminta oleh penjual itu sendiri, contohnya adalah penjual yang meminta jangka waktu tertentu terkait pembayaran yang akan dilakukan oleh pembeli yang disertakan dengan syarat batal jika tidak dipenuhi.

2. Perlindungan terhadap pembeli. Lain halnya dengan penjual, perlindungan terhadap pembeli umumnya diikuti dengan pemberian kuasa yang tidak bisa ditarik lagi, dengan tujuan yaitu jika penjual tidak memenuhi kewajibannya maka pembeli dapat melakukan penuntutan dan akan meminta ganti rugi sesuai dengan yang disepakati. Pembeli biasanya akan meminta perlindungan dengan meminta agar SHM tanah yang bersangkutan dipegang oleh pihak ketiga yang disepakati. Selain itu dengan adanya pemberian kuasa yang tidak dapat ditarik maka jika jual beli telah terlaksana, pembeli dapat melakukan peralihan hak terhadap tanah tersebut tanpa perlu kehadiran dari penjual sebelumnya.

Mengacu pada Pasal 1491 KUHPerdata, semestinya pihak penjual didalam melaksanakan transaksi terkait jual beli harus sebelumnya telah menjamin bahwa objek tersebut dikuasai dengan aman tanpa adanya intervensi dari pihak lainnya, serta perlu dijelaskan terkait hal-hal penting mengenai objek tersebut agar tidak terdapat

${ }^{15}$ Adjie, H. op.cit, h. 65 
cacat yang disembunyikan, dalam hal ini tindakan ini disebut juga sebagai tindakan preventif untuk mencegah terjadinya hal-hal yang nantinya akan dapat merugikan kedua pihak. Kemudian berikutnya mengenai perlindungan hukum represif apabila terjadi pelanggaran hukum, dalam hal ini penegakan hukumnya dapat berupa pemberian denda, ganti rugi, penjara, dan hukuman tambahan dan bagaimana cara yang akan ditempuh apabila terjadi sengketa. Kepada pihak pembeli yang memiliki itikad baik maupun karena salah satu pihak tidak bisa memenuhi yang dijanjikan, maka dapat memperoleh ganti rugi sebagaimana tercantum didalam Pasal 1267 KUHPerdata bahwa: terhadap pihak yang tidak memenuhi perikatan maka salah satu pihak dapat memaksa pihak yang satunya untuk memenuhi persetujuan atau menuntut pembatalan yang disertai dengan ganti rugi .“

Pemberian perlindungan hukum berkaitan denan pembatalan perjanjian pengikatan jual beli hak milik atas tanah dalam rangkan untuk para pihak agar dapat mengembalikan keadaan seperti sebelum perjanjian dibuat dapat dilakukan dengan cara para penjual mengembalikan pembayaran yang telah dilakukan oleh pembeli, dan penjual kembali mendapatkan hak terhadap tanahnya tersebut.

\section{Kesimpulan}

Akibat hukum yang timbul dari suatu perjanjian pengikatan jual beli yang telah dibatalkan terhadap perjanjian tersebut menjadi batal dengan kata lain seketika itu menjadi akhir dari perjanjian yang telah dibuat karena telah terjadi pembatalan oleh para pihak dan dengan itu pula untuk para pihak sepanjang diperlukan tidak terikat lagi dengan apa yang ditetapkan dalam Pasal 1266 dan Pasal 1267 KUH Perdata. Kemuadian para pihak akan di kenakan pembayaran denda yang berdasarkan jumlah nominalnya tersebut telah disepakati sebelumnya oleh kedua belah pihak baik itu terhadap penjual kepada pembeli atau sebaliknya terhap pembeli kepada penjual dalam waktu yang ditentukan yaitu untuk setiap hari keterlambatannya. Terhadap perlindungan hukum bagi para pihak yang timbul dari penyebab pembatalan perjanjian tersebut adalah bagaimana keadaan dapat dikembalikan seperti sebelum adanya perjanjian tersebut atau dapat kembali seperti semula, dimana pihak penjual harus mengembalikan uangnya kepada pembeli dan pembeli bisa mendapatkan uangnya kembali, sebaliknya atas pembatalan perjanjian itu penjual juga berhak memperoleh kembali hak milik atas tanahnya kembali.

Agar nantinya tidak terjadi wanprestasi sebaiknya bagi para pihak yang melaksanakan perjanjian tersebut dilaksanakan dengan itikad baik. Karena dari kehendak atau itikad yang tidak baik dari perbuatan yang tidak baik dalam hal perjanjian yang dibuat menimbulkan kerugia bagi salah satu pihak. Seharusnya para pihak segera memenuhi segala persyaratan yang telah ditentukan setelah menandatangani perjanjian pengikatan jual beli selanjutnya agar segera dapat melakukan proses peralihan hak setelah dilakukan penandatanganan akta jual beli di hadapan PPAT.

\section{Daftar Pustaka / Daftar Referensi}

\section{Buku:}


Adjie, H. (2013). Kebatalan Dan Pembatalan Akta Notaris, Jakarta:Refika Aditama

Projodikoro, W. (2003). Asas-Asas Hukum Perjanjian. Bandung: Sumur

Samudera, T. (2004). Hukum Pembuktian Dalam Acara Perdata, Bandung: Alumni

Soekanto. S. dan Mamudji, S. (2007). Penelitian Hukum Normatif: Suatu Tinjauan Singkat. Jakarta: PT. Raja Grafindo Persada

Subekti, R. (2002). Hukum Perjanjian. Jakarta: PT. Intermasa

\section{Jurnal:}

Alfiansyah, A. (2015). Urgensi Perjanjian Pengikatan Jual Beli (Ppjb) Hak Atas Tanah yang Dibuat oleh Notaris. Kumpulan Jurnal Mahasiswa Fakultas Hukum.1-21

Ardianti, M., \& Handayani, I. G. A. K. R. (2018). PENYALAHGUNAAN WEWENANG PENERIMA KUASA DALAM PERJANJIAN PERIKATAN JUAL BELI TANAH DAN KUASA MENJUAL (Putusan Nomor: 173/K/Pdt/2012). Jurnal Repertorium, 5(1)

BASWEDAN, T. B. T. (2014). Kajian Yuridis Pembatalan Akta Pengikatan Jual Beli (Pjb) Tanah yang Dibuat Dihadapan Notaris. PREMISE LAW JURNAL, 4.1-18

Dewi, R. P., \& Purwadi, H. (2017). PEMBATALAN AKTA PERJANJIAN PENGIKATAN JUAL BELI AKIBAT WANPRESTASI (Studi Kasus Putusan Nomor: 200/Pdt. G/2012/PN. Jkt. Sel). Jurnal Repertorium, 4(2).

Sancaya, I. W. W. (2013). Kekuatan Mengikat Perjanjian Nominee dalam Penguasaan Hak Milik Atas Tanah. Jurnal Magister Hukum Udayana (Udayana Master Law Journal), 2(3)

Santosa, K., \& Hanim, L. (2017). PERLINDUNGAN HUKUM BAGI PIHAK-PIHAK YANG BERITIKAD BAIK DALAM PEMBATALAN PERJANJIAN JUAL BELI TANAH DAN BANGUNAN (Studi Kasus Nomor 29/Pdt. G/2014/PN. Wsb). Jurnal Akta, 4(2), 167-173

SITINJAK, MELDA NEHEMIA. Analisis Yuridis terhadap Perjanjian Pengikatan Jual Beli (Ppjb) Unit Apartemen sebagai Agunan dalam Perjanjian Kredit Investasi (Studi di Pt. bank Nationalnobu Tbk). PREMISE LAW JURNAL, 2016, 21

Sumardi, S. H. "KEDUDUKAN KUASA MENJUAL ATAS DASAR SURAT KETERANGAN NOTARIS TENTANG PEMBAYARAN LUNAS DALAM PEMBUATAN AKTA JUAL BELI BALIK NAMA." Act 